Acta Hispanica (2020) Supplementum II: 673-685

\title{
LAS RELACIONES HISPANOAMERICANAS A TRAVÉS DEL NO-DO, 1943-1956
}

\author{
CARMe Gil Pardo \\ Centro de Investigaciones Film-Historia, Universidad de Barcelona
}

Resumen: El artículo presenta las relaciones económicas, políticas y sociales entre la España del dictador, general Franco, y los países americanos de habla hispánica entre los años 1943 y 1956. El análisis ha sido realizado, por primera vez, a través del noticiario español No-Do.

Palabras clave: Franco, Hispanoamérica, Madre Patria, Día de la Hispanidad, No-Do

\begin{abstract}
The article presents the economic, political and social relations between the Spain of the dictator, General Franco, and the Spanish-speaking countries of America between the years 1943 and 1956. The analysis has been carried out, for the first time, through the Spanish Newsreel No-Do.
\end{abstract}

Keywords: Franco, Hispanic America, Motherland, Day of the Hispanidad, No-Do.

\section{Las relaciones hispanoamericanas}

El deseo de establecer lazos entre la Madre Patria y las antiguas colonias siempre ha existido y en la España de posguerra era de gran necesidad. El objetivo era recuperar la influencia política y cultural con los países latinoamericanos y que estos sirvieran de nexo ante los estados que formaban parte de los nuevos organismos internacionales en los cuales España no era admitida por su política a favor del Eje durante la Segunda Guerra Mundial. Las relaciones hispanoamericanas han sido objeto de numerosos estudios pero por primera vez abordamos esta situación desde las noticias que dió el noticiario español, No-Do.

\section{Fuentes consultadas}

Esta investigación ha tenido una fuente principal de información: el No-Do, en total se han consultado 417 No-Do's, el estudio va desde el año 1943 hasta el año 1956. Paralelamente, también se ha consultado la prensa del momento y la bibliografía pertinente.

\section{3. ¿Qué fue el No-Do?}

Los noticiarios no son patrimonio de ningún régimen político, todos los dirigentes de un país, sea democrático o dictatorial, ven la trascendencia que puede tener sobre la sociedad a la cual se dirigen. No-Do filmará hechos importantes, pero en la mayoría de 
las ocasiones comentará aquello que el espectador ve en la pantalla, no motivará a la reflexión de aquello que se ve, o incluso de lo que no se ve (Paz-Montero, 2002).

\section{España en la posguerra civil española}

Al término de la Guerra Civil española, consagró en España una dictadura durante casi cuarenta años. El final de la Segunda Guerra Mundial significó el ocaso de los regímenes fascistas europeos y el franquismo se encontraba durante unos años en una situación de aislamiento internacional. Pero la existencia de la Guerra Fría en el mundo de posguerra hizo posible que el franquismo, enemigo declarado del comunismo, superara las dificultades y consiguiera el reconocimiento internacional (Risques, 1999).

Cabe decir que a lo largo de los años el voto a favor o en contra de los países latinoamericanos variaría según los intereses económicos o el avance del comunismo. En 1949 cuatro países de América Latina: Brasil, Bolivia, Colombia y Perú, pidieron que se diera total libertad en las relaciones con la España de Franco. Sus razones fueron que mientras América Latina no mantenía relaciones con España, según lo acordado por la ONU, sí lo hacían Estados Unidos y Gran Bretaña. Además, se argumentaba la no intervención en asuntos propios del pueblo español.

\section{La situación económica en España}

Al final de la Guerra Civil española la economía de España estaba en una crisis que se vio agraviada con la política económica autárquica que imperaba en el estado español. En los primeros años de la posguerra España abastecía a Alemania de volframio. Franco pagaba sus deudas de la Guerra Civil con este metal y otros productos. Y España recibía material procedente de Argentina, escapando así al bloqueo aliado. Finalmente se llegó a un acuerdo con Norteamérica y Gran Bretaña, el 2 de mayo de 1944 se firmó la reanudación de las exportaciones de petróleo a España. Paralelamente, se recibía la ayuda de la República Argentina, si bien es cierto que la ayuda argentina se venía produciendo desde hacía tiempo. Estados Unidos y otros países, con gobiernos democráticos o no, aceptaron la ayuda argentina como un mal menor, si no se ayudaba a España ésta corría el riesgo de caer en una guerra civil y quizás también bajo la influencia comunista.

\section{La expulsión de España de los organismos surgidos después de la Segunda Guerra Mundial}

La conferencia fundacional de la Organización de las Naciones Unidas se celebró en San Francisco en junio de 1945. Días antes de su clausura, México propuso la no aceptación de países con un régimen que hubiera sido ayudado por países contrarios a los aliados. La propuesta de México fue aceptada. La delegación mexicana estuvo representada por el diplomático Luís Quintanilla, la negativa recogía las siguientes 
palabras: "es una hecho bien conocido que las fuerzas militares de la Italia fascista y de la Alemania nazi intervinieron abiertamente para colocar a Franco en el poder" (Sola Ayape, 1946: 13). Pero las medidas aprobadas por la ONU eran solo diplomáticas, no se extendían a sanciones económicas o militares. España también retiró a sus embajadores de los países que la habían sancionado, pero mantuvo a los funcionarios en sus respectivas embajadas.

\section{La actitud de Argentina hacia el gobierno español}

El 30 de octubre de 1946 se firmó un acuerdo entre Argentina y España, la primera otorgaba un gran crédito para la compra de trigo argentino. Madrid debía devolver el crédito con una tasa de interés anual del 2,75\%. El tratado también estipulaba que se podrían comprar otros productos alimentarios. A cambio, España enviaría cada año a Argentina, hasta el 1951, hierro, plomo, entre otros productos.

\section{Momentos decisivos que ayudaron, indirectamente, a la política del franquismo}

Otros acontecimientos a escala mundial favorecerían al Caudillo. En 1949 Mao Zedong había instaurado la República Popular de la China. Y el 24 de junio de 1950 Corea del Norte invadió Corea del Sur, en algunos países ya se pedía la inclusión de Franco, que se había ofrecido a enviar tropas a Corea del Sur. Ante el cariz que estaba tomando la expansión del comunismo, el 4 de noviembre de 1950 la Asamblea General de las Naciones Unidas aprobó el regreso de los embajadores a Madrid.

\section{9. ¿Qué noticias editará No-Do de 1943 a 1956 ?}

Desde el mismo momento en que empezó la difusión del noticiario, aparecieron noticias de países latinos. En 1943 de Argentina se mostraban concursos, partidos de fútbol y reportajes de moda, entre otros. (No-Do n $3 \mathrm{~A}, 4 \mathrm{~A}, 13 / 18 \mathrm{~A}, 20 \mathrm{~A}, 21 \mathrm{~B}, 23 \mathrm{~A}$ y 28A). A pesar de que las cámaras no lo grabaron, de Argentina este año llegó carne, trigo.

De Brasil se visionó su celebración de independencia ( $\left.\mathrm{n}^{\circ} 44 \mathrm{~B}\right)$.

Del Perú se mostró su fiesta nacional $\left(n^{\circ} 44 \mathrm{~B}\right)$ y el que fue muy importante, el embajador del Perú en España presentó sus credenciales a Franco ( $\left.n^{\circ} 51\right)$.

Una festividad muy celebrada en estos años era el Día de la Raza o Día de la Hispanidad ( $\mathrm{n}^{\circ} 11 \mathrm{~A}$ y $43 \mathrm{~A}$ ), fiesta instaurada con la finalidad de conmemorar unos hechos que unieran España con la América Latina.

Dentro del acercamiento que el estado de Franco buscaba con América Latina, destacan los viajes del buque escuela Juan Sebastián Elcano $\left(\mathrm{n}^{\circ} 7 \mathrm{~A}\right)$, después de la Guerra Civil española este fue el primer viaje que realizó. A destacar el comentario de la voz en off del documental: "[...] visitarán las naciones de nuestra fe, nuestra raza y nuestro idioma $[\ldots]$... 
Al final de 1943, el noticiario hizo referencia a un volcán que había entrado en erupción en México ( $\left.n^{\circ} 21 \mathrm{~B}\right)$.

En 1944 el gobierno español veía aproximarse el final de la contienda bélica y el que era muy importante para un régimen que había acercado posiciones con el Eje, la victoria sería para los aliados. Los noticiarios seguirán mostrando imágenes de deportes en Chile ( $\mathrm{n}^{\circ} 58 \mathrm{~A}$ ), exposiciones de arte en Argentina ( $\mathrm{n}^{\circ}$ 60B), erupción, una vez más, en México $\left(\mathrm{n}^{\circ}\right.$ 93A), fiesta del Centenario de la República Dominicana ( $\left.\mathrm{n}^{\circ} 76 \mathrm{~A}\right)$ etc. Y la posición militar de Brasil: patrullas aéreas de los EE.UU., protegiendo a los convoyes brasileños $\left(n^{\circ} 68 \mathrm{~A}\right)$.

De entre las noticias editadas en 1945 cabe destacar dos de gran relieve. Una era la inauguración, en la ciudad de Sevilla, de una residencia para estudiantes hispanoamericanos ( $\mathrm{n}^{\mathrm{o}}$ 117B). El otro hecho importante fue la conferencia Interamericana de Chapultepec en la cual participaron 20 países (n ${ }^{\circ} 123$ B). Convocada por México, la finalidad era reorganizar las relaciones interamericanas dentro del nuevo orden mundial, crear un tratado (Tratado Interamericano de Asistencia Recíproca - TIAR-1947) y organizarse dentro del nuevo panorama (Organización de Estados Americanos - OEA1948).

A finales del mes de abril llegó a España, procedente de Roma, Monseñor Antonio Caggiano, obispo de Rosario de Santa Fe (Argentina), su visita a Roma había sido motivada por el nombramiento que el Papa Pío XII hizo de 32 nuevos cardenales. NoDo filmó el encuentro entre el eclesiástico y Franco ( $\left.n^{\circ} 174 \mathrm{~A}\right)$.

El general Juan Domingo Perón presidió la firma, el 30 de octubre de 1946, del Convenio Comercial entre su país y España ( $n^{\circ}$ 201B). Argentina daba a España un crédito rotativo anual de 350 millones de pesos por tres años, con opción a renovarlo por otros dos años, el interés sería del 2,75\%, también le daba a España un préstamo de 400 millones de pesos, a ser devuelto en 25 años, que sería utilizado para el pago a Argentina de las importaciones realizadas por España entre 1942 y 1946, deuda que ya alcanzaba los 225,5 millones de pesos. Por su parte, España debía exportar a Argentina hierro, plomo, etc. Aceptó también la construcción de barcos para Argentina, se regularon la inmigración, las conexiones aéreas y marítimas. Un punto importante para Argentina era el derecho a establecer zonas francas en puertos españoles desde donde pudiera exportar sus mercancías al resto de Europa; se le ofreció el puerto de Cádiz. A finales del año las cámaras recogieron la llegada del buque-escuela argentino República del Plata al puerto de Cádiz (n 201B).

Paralelamente con los acuerdos comerciales, el general Perón recibió de manos del embajador español en la Argentina el Gran Collar de la Reina Isabel la Católica (nº 204A). Este mismo No-Do muestra imágenes de Perón y su esposa celebrando el Día de la Raza. Frecuentes fueron los partidos de fútbol entre equipos argentinos y españoles. Ampliamente editado por el noticiario fue la gira que el Club Atlético San Lorenzo de Almagro realizó por el continente europeo en 1946 y 1947 (n 208B; del 1947 son: $n^{\circ}$ 209A, 201B, 212A, 214A, 21B6, 242B y 244B) (Santacana, 2005). 
Con Cuba se inauguró una línea aérea entre La Habana y Madrid (nº 205 B). Y NoDo también informó de la renuncia del presidente del Brasil, Getulio Vargas, depuesto a finales de 1945. En el año 1947 el gobierno español no dejaba de mencionar a los nuevos presidentes de las repúblicas, como fue el caso del presidente de Uruguay, Tomás Berreta $\left(\mathrm{n}^{\circ} 223 \mathrm{~A}\right)$. Hay que destacar la llegada del nuevo embajador de la República Argentina a Madrid, Pedro Radio, (n 212A, 212B, 213A y 220A). En el año de su llegada, el nuevo embajador imponía condecoraciones a diferentes ministros y subsecretarios españoles del Departamento de Educación Popular ( $\mathrm{n}^{\circ}$ 260B). A principios de año llegó al puerto de Barcelona el buque argentino Río Dulce, así quedó inaugurada la ruta comercial entre Argentina y los puertos del Mediterráneo (n 215B). En estos primeros años el gobierno franquista organizó recepciones para ciudadanos argentinos, futbolistas, militares, artistas, etc. El propio Franco recibió con gran solemnidad a cadetes de la aviación argentinos ( $\mathrm{n}^{\circ} 258 \mathrm{~A}$ y $\left.258 \mathrm{~B}\right)$.

Pero la noticia estrella del año 1947 fue la visita de Eva Duarte de Perón ( $n^{\circ} 232 \mathrm{~A}$, 232B, 233A, 233B, 234A, 234B y 235B). Fue una gran propaganda para el régimen de Franco. Los comercios fueron cerrados durante cuatro horas, se dio fiesta a las escuelas y los sindicatos verticales alentaron a sus trabajadores a participar en los actos principales. El que no quiso recibir a Eva Perón fue el obispo de la Ciudad de Barcelona, el motivo era el pasado tanguista y de vida alegre de la esposa de Perón (Balagué, 2003: 57).

Después de la visita de Eva Perón, los representantes de los dos gobiernos se reunieron para negociar la deuda española. La sorpresa se hizo patente cuando los representantes del gobierno argentino manifestaron que se quería cobrar en dólares americanos (2003: 36). La visita de Eva ocasionó gastos económicos, por ello el alcalde de la ciudad condal pidió a algunos empresarios que ayudasen a paliar los gastos que había originado su visita (2003: 44). Desde Suiza, último país europeo que visitó Eva, se comunicó al gobierno español el deseo de la dama de regalar 2.000 tn. de trigo a repartir entre las cartillas de racionamiento de tercera clase en aquellas ciudades que ella había visitado. Este gesto hizo que se la recordara, aun hoy la gente habla del regalo de Eva con gratitud. Franco le otorgó la máxima condecoración del estado español: la Gran Cruz de Isabel la Católica.

En el año 1948 varios países de América Latina reanudaron las comunicaciones aéreas y marítimas con España: México (n 263B y 268 A; y de fecha 19-7-48 es el no 289B), Cuba ( $n^{\circ} 279 B$ ), Río de Janeiro ( $n^{\circ} 283 A$ ). El puerto de Valencia también fue puerto franco por lo que respecta al comercio con Argentina. Desde su puerto, un barco con bandera danesa cargaba naranjas con destino a Argentina ( $\mathrm{n}^{\circ}$ 264B). Pero hacia mediados del año llegó a España un importante cargamento de trigo, el barco español Eolo descargó 6.900 tn. (n $\left.{ }^{\circ} 276 B\right)$. Estos envíos eran frutos del pacto que establecía la llegada de 300.000 tn. de trigo en 1948. Las exportaciones españolas seguían lo marcado: madera, hierro, etc., entre otras materias primas y productos textiles manufacturados. Este acuerdo hispano-argentino fue filmado por No-Do ( $n^{\circ} 275 \mathrm{~A}$ y B y 277B), una gran multitud de 
ciudadanos de Madrid se manifestó delante de la embajada argentina para demostrar su agradecimiento ( $\left.\mathrm{n}^{\circ} 275 \mathrm{~B}\right)$.

El gobierno del Franco logró que algunos países entregaran sus banderas al museo del ejército, eran las de aquellos países que defendían España en la ONU. Argentina, según muestran las cámaras, fue la primera en hacerlo (nº 261A), después lo hizo Paraguay (n $\mathrm{n}^{\circ}$ 299B). Previamente a la llegada de Eva Perón, de las banderas y de la misión militar argentina que visitó Madrid ( $\mathrm{n}^{\circ}$ 263B), el embajador español en Argentina, Sr. Areilza, volvía de Buenos Aires para informar al gobierno español del trabajo que se le había encomendado. El embajador marchó a Argentina con instrucciones de conseguir el apoyo de este país en los foros internacionales ante los demás gobiernos sudamericanos.

A mediados del año 1948 la República Dominicana presentó credenciales ( $\mathrm{n}^{\circ} 281 \mathrm{~B}$ ). Paralelamente, marchó para el Perú el nuevo embajador español, Sr. Castiella ( $n^{\circ} 284 \mathrm{~B}$ ). Al lado de estas visitas diplomáticas, llegaban a España personajes famosos del mundo del cine y la canción. La estrella argentina Zully Moreno y su marido el director de cine Luis César Amadori ( $n^{\circ} 277$ A y 282A), la artista María Félix ( $n^{\circ} 278 B$ ) y el actor y cantante Jorge Negrete $\left(\mathrm{n}^{\circ}\right.$ 284A). Las muestras de hermandad con América Latina seguían dándose a lo largo de todo el año. Madrid acogió un Congreso Hispano-Americano de Cine ( $\mathrm{n}^{\circ} 287$ B y 288A); una peregrinación a Santiago de Compostela con miembros de varios países sudamericanos $\left(\mathrm{n}^{\circ} 269 \mathrm{~A}\right)$ y a finales del mismo año el ministro de asuntos exteriores español, Martín-Artajo viajó a Buenos Aires, allí inauguró una cátedra española en la Universidad del Plata ( $\left.n^{\circ} 304 \mathrm{~B}\right)$.

El noticiario mostró los sucesos que a partir de abril del 1948 ve vivían en Colombia. El 30 de marzo se inauguró en Bogotá la IX Conferencia Panamericana, en la cual los EE.UU. tenían como máxima prioridad la lucha contra el comunismo. En las elecciones a la presidencia del país colombiano de 1945, salió elegido como máximo dignatario Mariano Ospina Pérez, pero sus opositores le reclamaron el final de su política represiva y uno de ellos fue asesinado. Las consecuencias de esta muerte fueron devastadoras. La ciudad quedó medio destruida. No-Do mostró las imágenes (nº 280A y 280B), pero cabe notar que la voz en off se expresaba en el idioma inglés. Esto supuso que el espectador español no entendiera bien por qué se daban disturbios en Colombia y no supiera ni el motivo, ni las consecuencias. La prensa informó de una manera muy sútil: mencionando que las sesiones habían estado iluminadas por las hogueras de los comunistas y si la conferencia no dio todo lo que se esperaba de ella fue debido a la revuelta comunista (Montsant, 1948: 6). Las cámaras también recogieron las recepciones de Franco a estudiantes hispano-americanos $\left(\mathrm{n}^{\circ} 281 \mathrm{~A}\right)$ y a marineros de Argentina a los cuales impuso la Cruz del Mérito Naval (nº 300A, 300B y 303B).

En 1949 No-Do editó pocas noticias sobre América Latina: deportes, erupción volcánica en México y Ecuador y la entrega de una bandera del Perú al museo del ejército español por parte del embajador de aquel país ( $n^{\circ} 321 B$ ). Pero el noticiario volvió a mostrar los disturbios ocurridos en Colombia ( $n^{\circ} 364 B$ ), la noticia volvió a tener la voz 
en off en inglés, y las imágenes eran en su mayoría las mismas que las aparecidas en los No-Do's de 1948.

La llegada de embajadores durante el año 1950 fue más frecuente que en fechas anteriores, poco a poco la política hostil contra el gobierno del dictador se iba suavizando. El primer embajador en llegar fue el Mariscal Ureta del Perú (n 368A), le siguió el Dr. Hertoz de Bolivia ( $\mathrm{n}^{\circ}$ 371B), el de Brasil (378A), el ministro de relaciones exteriores de Colombia ( $\mathrm{n}^{\circ} 389 \mathrm{~A}$ ), el embajador de El Salvador, que llegó junto con el de Irlanda ( $\mathrm{n}^{\circ}$ 406B), el de Argentina y el enviado extraordinario de Honduras ( $\mathrm{n}^{\circ} 413 \mathrm{~A}$ ), los de Nicaragua y Colombia ( $\left.\mathrm{n}^{\circ} 416 \mathrm{~B}\right)$. Seguían editando noticias sobre deportes, llegada de artistas y la celebración del Día de la Raza.

A mediados de año se celebró el II Certamen Cinematográfico Hispanoamericano, en su clausura fueron premiadas una película argentina, otra de México y una española ( $\mathrm{n}^{\circ}$ 383B y 387A). En estos certámenes el gobierno español quería evitar cualquier matiz político, prueba de ello es la presencia de México, país con el cual no se mantenían relaciones, estas se reemprendieron a partir de la muerte del dictador español en 1975. Estas reuniones de carácter cinematográfico recibieron el nombre de Congreso en el NoDo $\mathrm{n}^{\circ} 278 \mathrm{~B}$ (mayo del 1948), pero en el No-Do n ${ }^{\circ} 288 \mathrm{~A}$ (julio de 1948) ya se le nombra como Certamen, en clara alusión al sentido de concurso de películas que tenían (Cabaña, 1996).

Hacia finales de año, el No-Do mostró imágenes sobre los disturbios de Puerto Rico, el noticiario publicó la noticia con el título: Bajo el signo comunista del odio (n ${ }^{\circ}$ 411B). Pero como siempre, las noticias sobre los hechos no vinieron del No-Do. Los españoles tuvieron noticias de la prensa, el día 3 de noviembre se informó (EFE, 1950a: 8) que el atentado al presidente de los EE. UU., Truman estaba relacionado con la agitación comunista que vivía Puerto Rico. Al día siguiente se anunció: "El movimiento sedicioso de Puerto Rico ha sido totalmente dominado" (EFE, 1950b: 8).

El año 1951 se mostró el partido de fútbol que jugaba el campeón de Liga contra el campeón de la Copa del Generalísimo (n 462A). El ganador de este encuentro ganaba la Copa $\mathrm{M}^{\mathrm{a}}$ Eva Duarte de Perón. Este año presentaron las cartas credenciales los embajadores de Venezuela ( $n^{\circ} 423 \mathrm{~A}$ ), el Salvador ( $\left.n^{\circ} 428 \mathrm{~A}\right)$, Paraguay ( $\left.n^{\circ} 446 \mathrm{~B}\right)$, Panamá ( $\mathrm{n}^{\circ}$ 461B), la República Dominicana ( $\left.\mathrm{n}^{\circ} 467 \mathrm{~B}\right)$, Costa Rica ( $\left.{ }^{\circ} 435 \mathrm{~A}\right)$, embajadores de habla no hispana: Bélgica y Holanda ( $\left.\mathrm{n}^{\circ} 426 \mathrm{~A}\right)$, los Estados Unidos ( $\left.\mathrm{n}^{\circ} 427 \mathrm{~B}\right)$, Noruega $\left(n^{\circ} 428 A\right)$, Gran Bretaña ( $\left.n^{\circ} 429 A\right)$, Francia ( $n^{\circ} 429 B$ ), Italia y Dinamarca ( $\left.n^{\circ} 43 A\right)$, Filipinas (No-Do $n^{\circ} 433 \mathrm{~A}$ ) y del Irán ( $\left.\mathrm{n}^{\circ} 43 \mathrm{~A}\right)$. A Franco no solo vio reconocido su régimen dictatorial, sino que también recibió condecoraciones de Haití ( $\left.\mathrm{n}^{\circ} 423\right)$ y del Perú ( $\mathrm{n}^{\circ}$ 423B). Al mismo tiempo, la embajada de Chile en Madrid entregó condecoraciones al ministro de Marina español junto con otras personalidades también españolas $\left(\mathrm{n}^{\circ}\right.$ 425B).

El noticiario nos mostró las imágenes de un hecho de suma importancia para el campo del arte español: la inauguración que Franco, acompañado del ministro de Asuntos Exteriores del Perú, hizo de la Exposición Bienal del Arte Hispanoamericano. Este 
acontecimiento se encuadró dentro de la celebración del Día de la Raza (n 459A y 459B). No todos los artistas ni todos los países acogieron favorablemente la Bienal. El pintor Joan Miró se inhibió, Picasso instó a no acudir a la exposición, pero Dalí, con sus característicos discursos, se adhirió entusiásticamente. Algunos países organizaron una "contra-bienal" de París, famosa por la participación de Picasso, México y Caracas. También se opusieron artistas españoles en el exilio y artistas latinoamericanos (Rodríguez, 2008).

Importante para las relaciones hispanoamericanas fueron los Congresos Femeninos, celebrados bajo el patrocinio de la Falange Española. El I Congreso Femenino Hispanoamericano y de las Filipinas ( $\mathrm{n}^{\circ}$ 437B) tuvo la participación de 200 delegaciones desde América Latina y las Filipinas. El Congreso quiso que la Hispanidad fuera un vehículo integrador y un acuerdo sobre la labor de la mujer en el mundo hispánico. Todos estos acuerdos se fomentarían a través de los Círculos Culturales Femeninos Hispanoamericanos. La Sección Femenina de la Falange Española comenzó la construcción de la Comunidad Hispánica con los viajes de los Coros y Danzas (nº 291B, 439B, 548B y 582A) y el Congreso Hispanoamericano.

En el año 1952 llegaron nuevos embajadores a Madrid desde Francia (n 470B), Suiza, Honduras y Haití ( $\mathrm{n}^{\circ} 480 \mathrm{~A}$ ), los Estados Unidos ( $\left.\mathrm{n}^{\circ} 483 \mathrm{~A}\right)$, Ecuador ( $\left.\mathrm{n}^{\circ} 483 \mathrm{~B}\right)$, China, Arabia y Cuba ( $\left.\mathrm{n}^{\circ} 499 \mathrm{~A}\right)$, República Federal de Alemania ( $\left.\mathrm{n}^{\circ} 51 \mathrm{~A}\right)$, Japón y Panamá (nº 518B). Con motivo de la festividad del 18 de julio, Franco ofreció una recepción a todos los representantes acreditados en España (nº 499B).

1952 fue un año crucial para el régimen fascista, en la ciudad de Barcelona se celebró el XXXV Congreso Eucarístico Internacional con la asistencia de 77 países. El respaldo de la Iglesia y la numerosa asistencia de países latinos significó el reconocimiento de un gobierno dictatorial que quiso ocultar, tras la fastuosidad de los actos celebrados, la verdadera situación, la represión, la vulneración de los derechos civiles y políticos, etc., en las que vivían la mayoría de los españoles ( $n^{\circ} 483 \mathrm{~A}$ ). A principios de año el noticiario informó del golpe de estado en Cuba ( $\mathrm{n}^{\circ}$ 481A y 482A), Fulgencio Batista huyó de Cuba y después de vivir en varios países finalmente moriría en 1973 en Marbella, localidad española. El acontecimiento que recibió más información, tanto del noticiario como de la prensa, fue la muerte de Eva Duarte de Perón (n 500B, 502B y 505A). La prensa llegó a afirmar: "El comentario general es que la muerte de doña Eva se debe al esfuerzo y la fatiga experimentada en su afán de favorecer a los trabajadores" (El Noticiario Universal, 1952: 7). No-Do también informó de las elecciones a la presidencia de Chile ( $\mathrm{n}^{\circ}$ 513B).

En 1953 presentaron cartas credenciales los embajadores de Uruguay y Chile ( $\mathrm{n}^{\circ}$ 568B), también lo hicieron los embajadores de Siria y Estados Unidos ( $\mathrm{n}^{\circ}$ 537B). A finales del mes de mayo llegaron a Madrid los componentes del I Congreso Iberoamericano $\left(\mathrm{n}^{\circ}\right.$ 544B). La finalidad de este Congreso era estrechar los lazos económicos entre los países de habla hispana, incluso se anunció que ante la dificultad de divisas se podría recurrir al intercambio de productos. Las demás noticias de este año venían referidas a temas diversos; tenis de mesa, toreros, fiestas colombinas, etc. 
El 1954 empezaba dándonos información de la profunda transformación que experimentaba Caracas, ( $\mathrm{n}^{\circ}$ 579B). El presidente de Venezuela inauguró la Conferencia Interamericana con la asistencia de todas las repúblicas del continente americano. La finalidad de esta Conferencia era la adopción de medidas ante el peligro de una penetración comunista. John Foster Dulles, en representación de los Estados Unidos, advertía sobre las maquinaciones de Moscú en su afán de extender su influencia comunista $\left(n^{\circ} 582 \mathrm{~A}\right)$.

El régimen de Franco siempre acogía a todos los dictadores latinos que habían sido depuestos de sus cargos. Marcos Pérez Giménez, presidente de Venezuela (nº 526B) vivió en diferentes países, pero se acogió a la protección de Franco y vivió en España hasta su muerte en 2001. Ampliamente filmadas fueron las visitas que Rafael Leónidas Trujillo hizo a España. La primera muestra su visita a Vigo ( ${ }^{\circ}$ 597A) y a Madrid (nº 597B), el día de su llegada se decretó fiesta escolar y la ciudad de Madrid fue engalanada para darle una espectacular bienvenida. Después de su marcha de Madrid ( $\mathrm{n}^{\circ}$ 598A) estuvo en Barcelona ( $\mathrm{n}^{\circ}$ 598B). A su muerte fue enterrado en París, pero después su cadáver fue trasladado a España. Durante la dictadura de Rafael Leónidas Trujillo las relaciones con Franco fueron inmejorables. También en este año fueron filmados diversos actos: en la Escuela Naval de Marina, España, la marina dominicana hizo entrega de una bandera, una placa y se leyó un mensaje de Rafael Leónidas Trujillo ( $\mathrm{n}^{\circ}$ 613A), y en la embajada dominicana en Madrid se impusieron condecoraciones a militares españoles $\left(\mathrm{n}^{\circ} 617 \mathrm{~A}\right)$. Y Y no es menos cierto que la dictadura de Trujillo acogió a exiliados españoles después de la Guerra Civil española, tal es el caso de Manuel Peña Batlle, "obligado" a desempeñar cargos políticos dentro del gobierno de Trujillo (Martín y Carvajal, 2002: 213); en otros casos, no obstante, persiguió y asesinó a algunos españoles exiliados que habían pasado por la República Dominicana (Martín y Carvajal, 2002: 215; Alonso, 2005).

No-Do filmó e informó sobre la reunión urgente del Comité de Seguridad de las Naciones Unidas, reunido para tratar el golpe de Estado de Guatemala ( $\mathrm{n}^{\circ}$ 600A). Castillo Armas, el nuevo presidente guatemalteco fue recibido por una gran multitud a su llegada a Guatemala procedente de Honduras ( $\left.\mathrm{n}^{\circ} 603 \mathrm{~A}\right)$. Ni el noticiario ni la prensa española mencionaron en ningún momento los intereses económicos de los Estados Unidos en este golpe de estado, solo mencionaron ataques comunistas (EFE, 1954a: 8). Otro país latinoamericano que protagonizó un movimiento independentista, respeto a los Estados Unidos, fue Puerto Rico. Las imágenes que llegaron a las pantallas españolas fueron de un país en paro que reclamaba mejoras salariales $\left(\mathrm{n}^{\circ} 605 \mathrm{~A}\right)$.

A finales de año las cámaras mostraron la subida al poder de Alfredo Stroessner, presidente del Paraguay entre 1954 y 1989. Mostraba simpatía por los nazis y a varios de ellos les dio asilo, como en el caso del médico nazi Josef Mengele. A su toma de poder, en 1954, asistió el general Perón ( $\mathrm{n}^{\circ}$ 610A). La última revuelta política que el noticiario nos muestra este año corresponde a Brasil ( $\mathrm{n}^{\circ}$ 610B). A raíz del suicidio de Getulio Vargas, el país conoció una serie de disturbios, la voz en off anuncia que el ejército se prepara ante posibles manifestaciones comunistas y la prensa española (EFE, 1954b: 8) 
relata que algunos edificios de los Estados Unidos están siendo atacados por el pueblo brasileño (Ayllón, 2007). Solo un No-Do informa sobre la presentación de credenciales, la del nuevo embajador de las Filipinas ( $\mathrm{n}^{\circ}$ 619B).

En 1955 las cámaras recogen la presentación de credenciales por parte de los Estados Unidos (n 639A) y la Arabia Saudí (n ${ }^{\circ}$ 67A). En el mes de julio y celebrando el 18 del mismo mes, Franco ofreció una recepción a todos los diplomáticos acreditados en Madrid ( $\mathrm{n}^{\circ}$ 655A). Franco está muy presente en las jornadas del Congreso Iberoamericano de Municipios ( $\mathrm{n}^{\circ}$ 651B, 652B y 673B).

Hacia finales de año llegaron las noticias de los graves incidentes que vivía Argentina $\left(\mathrm{n}^{\circ}\right.$ 660A, 664A y 666B). La prensa también informó ampliamente (EFE, 1955a: 12; 1955b: 11; 1955c: 15). Un año después de la muerte de Getulio Vargas, Brasil vivía a+n en un estado de emergencia con Nereu de Oliveira Ramos, presidente interino de la nación. No-Do informó que el ejército estaba en alerta ante el peligro de que "elementos extraños" dieran un golpe de estado (n 673B). En un No-Do de fecha 26 de diciembre se informó que el 9 del mismo mes (el noticiario siempre daba las noticias con un cierto retraso) España había sido admitida en la ONU, la injusticia había sido reparada. Delante del Palacio de Oriente de la capital española se concentró un gran número de personas que vitoreaban a Franco ( $\mathrm{n}^{\circ}$ 677A). El último reportaje de este año fue dedicado a Venezuela. El Ministro de Gobernación español, Blas Pérez González, visitó junto al presidente venezolano Marcos Pérez Jiménez las obras que este último estaba llevando a cabo en su país con la finalidad de modernizarlo (n $n^{\circ}$ 677B). Como en todos los demás años, en este también hubo noticias sobre deportes, cinema, etc.

A principios de 1956 el presidente de Brasil, el anticomunista Juscelino Kubitschek, visitó España (nº 682A y 682B). Franco le otorgó el Collar de la Gran Cruz de Isabel la Católica y le nombró miembro de Honor del Instituto de Cultura Hispánica. Las imágenes que anteriormente nos habían mostrado una Argentina plenamente entregada al general Perón, ahora lo hacían con Aramburu, el nuevo presidente. Trescientas mil personas aplaudieron la nueva política llevada a cabo por el presidente ( $n^{\circ}$ 683B). En Panamá tuvo lugar una reunión de países americanos, en total 18, entre ellos los Estados Unidos que fue representado por el propio presidente Eisenhower. La finalidad era establecer una unión panamericana para fomentar la economía, evitar tensiones ante el creciente malestar internacional (la posible influencia comunista) y crear, a petición de los Estados Unidos, una comisión interamericana para el desarrollo de la energía atómica (n $\mathrm{n}^{\mathrm{o}}$ 709B).

La modernización de Venezuela ahora se veía en la incrementación de petróleo en el lago Maracaibo, modernas instalaciones que posteriormente harían llegar su producto a las refinerías de los Estados Unidos y Europa, tal como se anunció ( $\left.\mathrm{n}^{\circ} 715 \mathrm{~B}\right)$. A finales de año llegó el presidente de Costa Rica, José Figueres, pero esta visita tenía, por parte del presidente costarricense, un carácter privado. El presidente quería conocer diferentes poblaciones de Cataluña de donde provenían sus antepasados ( $\mathrm{n}^{\circ} 724 \mathrm{~A}$ ). Pero a pesar de la privacidad de la visita, el gobierno del general Franco quiso mostrarse con una 
actitud tolerante hacia un presidente de ideas contrarias a la dictadura de Franco. Como en todos los demás, años este también mostrará imágenes deportivas, exposiciones de cerámica, entre otras.

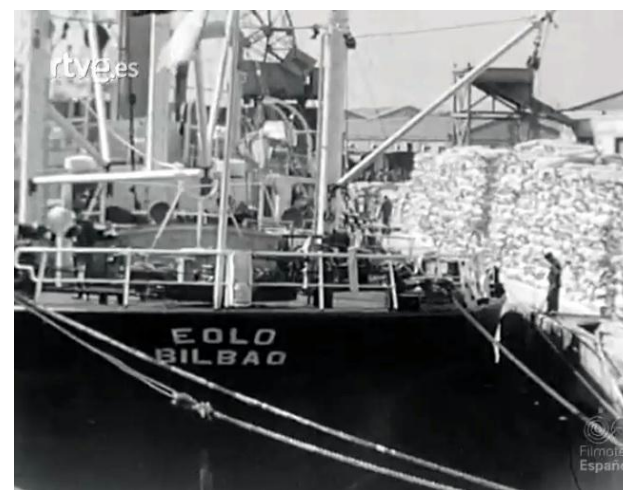

Archivo Histórico de No-Do, no 276B, 19/4/48-Llegada de cereal argentino

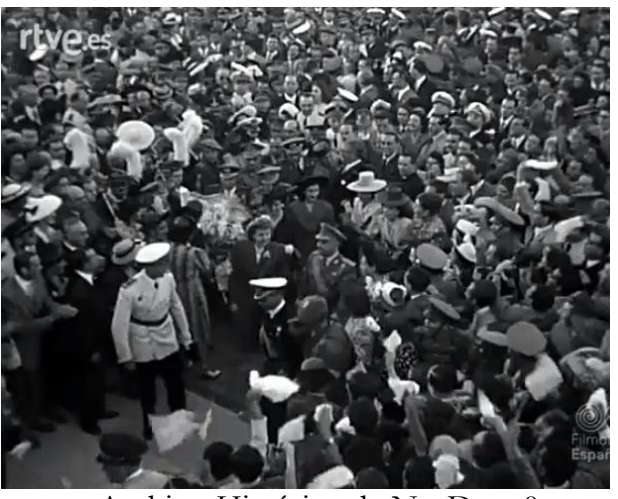

Archivo Histórico de No-Do, $\mathrm{n}^{\circ}$ 232A, 16/6/47. Llegada de Eva

Duarte de Perón a España

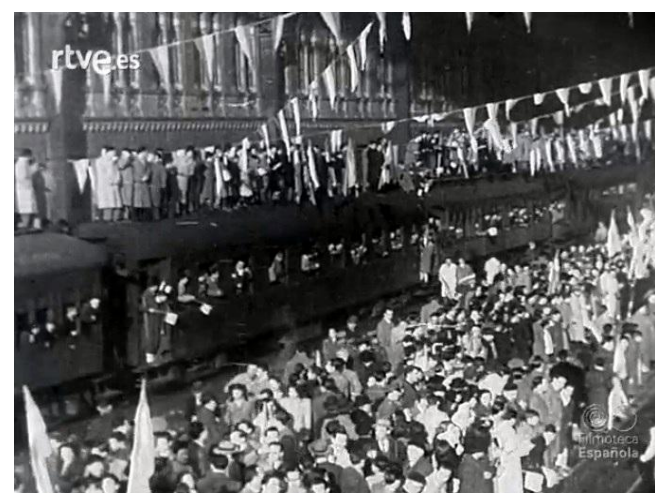

Archivo Histórico de No-Do, no $212 \mathrm{~A}$, 27/1/47. Llegada del embajador argentino, Pedro Radio

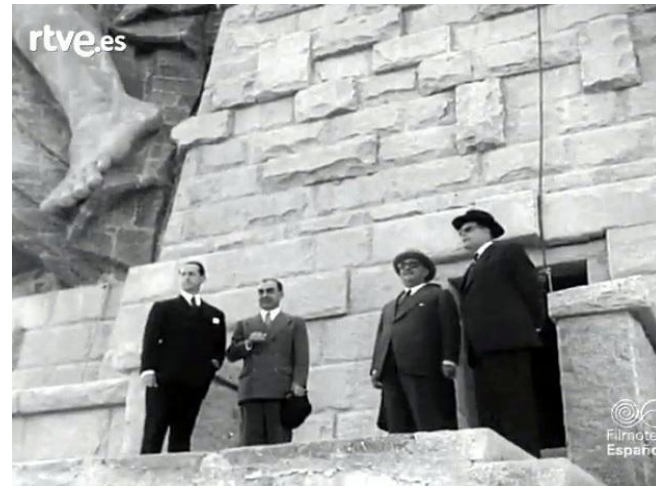

Archivo Histórico de No-Do, $\mathrm{n}^{\circ}$ 598A, 14/6/54, la visita de R.L.Trujillo a España 


\section{Referencias bibliográficas}

Alonso, Francisco Javier (2005). La alianza de dos generalísimos. Relaciones diplomáticas Franco-Trujillo. Santo Domingo: Fundación García Arévalo.

Ayllón, Bruno (2007). Las relaciones Hispano-Brasileñas. De la mutua irrellevància a la asociación estratègica (1945-2005). Salamanca: Universidad de Salamanca.

Balagué, Carles (2003). Històries de la Barcelona oculta. Barcelona: Ed. Planeta.

Cabaña, Miguel (1996). Política artística del franquismo. Madrid: Consejo Superior de Investigaciones Científicas.

EFE (1950a). El atentado frustrado contra Truman fue fraguado en Puerto Rico. La Vanguardia Española, 3-11-1950. 8.

EFE (1950b). El movimiento sedicioso de Puerto Rico ha sido totalmente dominado. La Vanguardia Española, 4-11-1950. 8.

EFE (1954a). Ataques comunistas en Guatemala. La Vanguardia Española, 3-6-1954. 8.

EFE (1954b). Edificios de los Estados Unidos están atacados. La Vanguardia Española, 26-8-1954. 8.

EFE (1955a). Noticias sobre Argentina. La Vanguardia Española, 25-9-1955. 12.

EFE (1955b). Noticias sobre Argentina. La Vanguardia Española, 28-10-1955. 11.

EFE (1955c). Noticias sobre Argentina. La Vanguardia Española, 4-9-1955. 15.

La muerte de Eva Perón (1952). El Noticiario Universal, 28-7-1952. 7.

Martín, Julio - Carvajal, Pedro (2002). El exilio español (1936-1978). Barcelona: Ed. Planeta.

Montsant, O. (1948). Balance argentino de la Conferencia de Bogotá. La Vanguardia, 11 5-1948, 6.

No-Do: del año 1943 al año 1956.

Paz, Maria Antonia - Montero, Julio (2002 ). Creando la realidad. El Cine Informativo 1895-1945. Barcelona: Ariel.

Risques, Manuel (dir.) (1999). 1943-1953 Història de la Catalunya Contemporània. Barcelona: Ed. Pòrtic.

Rodríguez, Araceli (2008). Un franquismo de cine. La imagen política del Régimen en el noticiario NO-DO (1943-1959). Madrid: Ed. Rialp.

Santacana, Carles (2005). El Barça i el franquisme. Crònica d'uns anys decisius per a Catalunya (1968-1978). Barcelona: Ed. Mina.

Sola Ayape, Carlos (2016). De Cárdenas a Echevarría: los 12 puntos de la política exterior de México hacia la España de Franco (1936-1975). Foro Internacional, 56/224. 321-377. Vinyes, Ricard (2010). Irredentas. Las presas políticas y sus hijos en las cárceles franquistas. Madrid: Ed. Planeta. 
Carme Gil Pardo

\section{Centros de documentación consultados}

Biblioteca de Catalunya (Barcelona)

Casa de l'Ardiaca (Barcelona)

Centre de Documentació i Estudis del F. C. Barcelona

Centre d'Investigacions Film-Història (UB)

Filmoteca Española (Madrid) 